\title{
The French SAS business
}

\section{entity}

\author{
by Frank Wooldridge
}

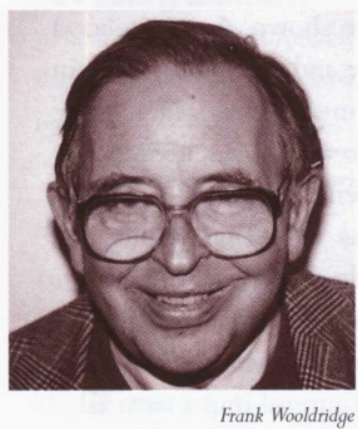

The French simplified share company (société par actions simplifiée, SAS) was introduced in France by Law No. 84-1 of 3 January 1994, which added a number of provisions to Law No. 56-537 governing commercial companies and partnerships of 24 July 1966. These provisions appear immediately below those which govern the société en commandite par actions (SCA), a type of corporation of which some members do not enjoy limited liability. The provisions governing the SCA appear after those governing the société anonyme (SA), which is equivalent to the English public limited liability company.

The third paragraph of art. 262-1 of the Law of 24 July 1966 (as amended) provides that in so far as they are compatible with the rules governing the SAS, the rules governing the SA, with the. exception of those contained in art. 89 to $177-1$, are applicable thereto. Articles 89-177-1 contain rules governing the traditional management structure of SAs (i.e. those with a conseil d'administration or board of directors), whilst art. 118-150 contain provisions governing the alternative system with an executive board (directoire) and supervisory board (conseil de surveillance). Articles 151 to $177-1$ principally concern general meetings, voting rights, and rights to documents and information. In applying the relevant tasks, the powers of the board of directors or the president of an SA are exercised by the president of the SAS, or those of the managers so designated in the company's statutes. The SAS may employ different forms of corporate governance from those familiar in the SA. It benefits from limited liability and a considerable degree of contractual freedom. The latter may be subject to some abuses however. Furthermore, businessmen who do not benefit from adequate legal advice may sometimes fail to provide, or provide adequately, for certain contingencies such as the convocation of meetings or quorums, and the courts are likely to be required on occasions to interpret their defective agreements. However, forms and precedents would seem likely to be devised for the use of persons contemplating the formation of an SAS.

The new entity was introduced to combat certain rigidities in French law governing such entities as the SA and the SARL (société a responsabilité limitée - private limited liability company), which could not always be overcome by means of the introduction of special provisions in the company's statutes, or by means of the provisions of shareholders agreements, which were sometimes of doubtful validity. When the SAS was first introduced it was made subject to two significant limitations, one of which was removed by art. 3 of Law No. 99-587 of 12 July 1999, which made substantial amendments to Law No. 941 of 3 January 1994. The limitation which remains is contained in Article 262-3 of the Law of 24 July 1966 (as amended), which provides that an SAS may not offer its shares for subscription by the public.

The removal of the first-mentioned limitation by the Law of July 121994 has greatly increased the scope of the SAS. Such a company was originally required by the first paragraph of art. 261-1 be made up of members which were sociétés (companies or partnerships) having a capital of at least FF 1,500,000. Such a company was also open to certain public undertakings belonging to the state. These limitations have meant that the SAS seems to have been used, at first, principally as a medium for co-operation between different companies, sometimes situated in different countries. It has the advantages over the EEIG (European Economic Interest Grouping) or its French counterpart, the GIE, that it can have as one of its objects the earning of profits, and that members are only subject to limited liability, and not (as in the GIE or EEIG) to joint and several unlimited liability for the debts of the entity. An SAS may also prove useful as the dominant company in a group of undertakings.

The law of 12 July 1999 removed the limitations contained in the above paragraph. The first paragraph of art. 161-1 provides that an SAS may be formed by one or more persons whose liability for the debts of the company only extends to the amount of their agreed contributions. It apparently follows from this not entirely clearly-drafted provision, that natural as well as legal persons may be members of an SAS because, in so far as companies may be members of such an entity, their liability is usually limited; thus if only such bodies qualified for membership of an SAS, there was little or no need to include a statement as to liability. The unsatisfactory draftsmanship of this provision probably results from the fact that the new provisions of art. 3 of 
Law 99-587 owe their existence to a parliamentary amendment to a bill essentially concerned with research and innovation, which unfortunately did not receive the detailed examination usually reserved for provisions of company law. It seems clear from the travaux préparatoires that the relevant provisions were intended to cover both legal and natural persons (note in this sense Germain, JCP, 1994, 1.379-9). The new provisions imposed no limitation as to the capital of such persons; however the minimum capital of an SAS is still required to be FF 250,000. Thus, art. 3 of the Law of 12 July 1999 opened the SAS to a much wider range of persons, as well as permitting the single member SAS (which may, as with German one-man companies, be used by sole entrepreneurs and as a subsidiary), art. 261-1, paragraph I, provides that where an SAS has only one member, such a simple member may exercise the powers granted to the 'members' where a collective decision is provided for. If the membership of an SAS falls below, the provisions of art. 1444-5 of the Civil Code remain inapplicable. This text provides that if all the shares of a company or partnership are held by one person, the company shall not be automatically dissolved but it may be dissolved at the request of any interested party if the situation has not been regularised within one year.

It will be noted that an SAS is not treated as an SA (public company or société anonyme), but rather as a type of share company (société par actions). For this reason, the Community company law directives are probably not applicable to it. However, according to art. 32 of Law No 93-1353 the SAS is taxed as a public company, even though it may well be thought of as being more similar to a private one; indeed it seems to have been to some extent inspired by the Dutch besloten Vennotschap (private or closed company with limited liability). The members of an SAS are called associés, a word which emphasises the element of personal cooperation (intuitus personae) between them. The 'personalistic' character of an SAS is stressed by Guyon and other commentators.

\section{SIGNIFICANCE OF THE STATUTES}

It is obvious from the provisions of Law 94-1 of 3 January 1994 that the SAS was intended to be a flexible form (note in this sense, Guyon, Die Société par Actions Simplifiée (SAS) - eine neue Gesellschaftsform in Frankreich, ZGR, 1994, p. 551) and combines the advantages of legal personality and a considerable degree of contractual freedom. Those features are already present in the French GIE (groupement d'intérêt économique) and in the EEIG, but as emphasised above, these bodies have certain disadvantages.

\section{Collective decisions}

As has already been indicated, the rules governing general meetings and the management of an SAS are made inapplicable to the SAS by art. 262-1 of the Law of 24 July 1966 (as amended). These rules may be replaced by specific provisions in the company's statutes. Thus, art. 262-10, paragraph 1 provides that the statutes determine the decisions which must be taken collectively by the members, in accordance with the forms and conditions which they prescribe. However, paragraph 2 of this article provides that certain decisions must be taken collectively; the collectivity referred to in this case will be the members (or perhaps, if the statutes so provide), the managers of the SAS. Such decisions relate to the increase and reduction of the company's capital, the redemption of its shares, the nomination of its statutory auditors, the approval of its annual accounts and the allocation of the profits, the company's merger with another company, and its division or liquidation.

General meetings of an SAS may be replaced by a written consultation of members, or by a document signed by all of them if the statutes so provide. The general meetings of such a company may be given greater or lesser powers than that of an SA. Individual members may also be given special powers by the statutes. The latter may determine the period of notice for meetings, the persons entitled to call them, the necessary quorum for meetings, and the required majorities for decisions. The statutes may also provide that persons who are not members may participate in certain decisions. Shareholders' agreements as to voting would also seem to be permissible, and particular shareholders may also hold different classes of shares, which entitle them to different voting rights.

\section{Management of the company}

The considerable liberty which is given to an SAS to prescribe by statutes how the members of the company shall exercise their powers, and what powers shall be given to them, is paralleled by the equally flexible position in relation to the organisation and functioning of the management of the company. The SAS does not need to have a conseil d'administration (board of directors) or a directoire (executive board) and a conseil de surveillance (supervisory board), but it may if it wishes adopt one of these two statutory models or combine features of both of them. The managers may be legal or natural persons and do not have to be members of the company. Managers may be appointed for a limited time or for life. The carrying out of particular transactions may be made subject to the approval of the general meeting of (if one exists) to that of the supervisory board.

\section{Certain flexible rules}

The rules governing the transfer of shares contained in art. 26214 and 262-15, and those concerning the exclusion of members contained in art. 262-17, have a flexible character because members are not bound to include them in the statutes, and are able to a greater or lesser extent, to determine the details of the relevant statutory provisions. Because of their detail, these rules receive separate consideration below: it follows from art. 262-21 that they are inapplicable to single member companies.

\section{MANDATORY RULES GOVERNING THE SAS}

Certain of the mandatory rules have already been considered above. These include those contained in art. 262-0 of the Law of 24 July 1996, as amended, requiring a collective decision of the members of the company in certain laws, and requiring the management report, annual accounts and consolidated accounts of a single member company to be drawn up by the president thereof, and approved by the single member after receiving a report from the statutory auditor within six months of the end of the financial year.

As mentioned above, certain of the mandatory rules governing the SAS, including the requirement that its capital should be at least FF 1,500,000 have been abrogated. This is also true of the former requirement contained in art. 262-2 that the shares of an SAS should be fully paid up, as well as the 
requirement that all its members should be companies or partnerships. However, a certain number of mandatory rules are still applicable to the SAS. Thus, as already indicated, an SAS may not request members of the public to subscribe for its shares. These may not be in bearer form.

\section{Representative powers of the president}

The most important of the mandatory requirements is considered by Guyon (op. cit., p. 505) to be that contained in art. 262-7, which is obviously intended to protect third parties. This text is clearly influenced by the provisions of the First Directive on Company Law (OJ Special Edition 1968(1), pp. 41-45). It provides that the company is represented in relation to third parties by a president designated in accordance with the requirements laid down by the statutes. The president is said to have the most extensive powers of acting in all circumstances in the name of the company within the limits of its objects. Furthermore, the company is deemed to be bound even by the acts of the president in relation to third parties which do not come within the scope of the objects of the company, except where he can prove that the third party knew that the act was outside the company's objects or he could not ignore that it was in the relevant circumstances; however the mere publication of the statutes is not treated as evidence of the latter. Finally, rules in the statutes limiting the powers of the president may not be invoked as against third parties.

If the president of an SAS is a legal as opposed to a natural person art. 262-8 provides that the managers thereof are subject to the same requirements, obligations and liabilities as if they had carried out the functions of president themselves. Although the powers of representation of the president are unlimited and illimitable in relation to third parties, it would seem possible to limit their exercise in relation to the company itself. Such internal powers might possibly be exercised instead by some other organ of the company. (Note the comprehensive article by Kandler and Seske, 'Die Société par Actions Simplifée (SAS) Schaffung einer vereinfachten "Aktiengesellschaft französischen Rechts"', Die AG, 1994, p. 447 , at p. 449 in this sense.)

\section{Managers' liabilities}

According to art. 262-9, the rules governing the responsibilities of the members of the board of directors and the executive board of SAS are applicable to the president and the managers of an SAS. Thus, according to art. 244(1) of the Law of 24 July 1966, they are liable in damages for defective management, and for breaches of their legal duties and of the company's statutes. Such a breach of the-statutes may occur where the managers exceed their managerial or representative powers. If a defective managerial measure has led to a depletion of the company's assets, those responsible for it may, in accordance with art. 180 of the Law No. 85/98 of 25 January 1985 , be required to fulfil the company's obligations. This law places a similar burden on de facto managers, who have been acting as such but have not been properly appointed.

\section{Rules governing certain categories of agreement}

Article 262-11 contains a rule rather similar to that contained in art. 101 of the Law of 24 July 1966 (as amended) governing certain agreements entered into by public companies. However, the scope of art. 262-11 is less extensive than that of art. 101 . According to art. 262-11, the statutory auditor is required to make a report to the members on agreements entered into directly, or through an intermediary, between the company and its president or its managers. The members are requested to decide on this report. Agreements which are not approved by the members cannot be challenged as far as third parties are concerned, but the interested party, the president and the other managers may be required to pay damages to the company if the agreement has prejudicial consequences for it.

\section{FUTURE USE}

It is difficult to predict the future of the SAS following its 'liberalisation' in 1999. When the new regime comes to be more generally understood, the SAS may well tend to supplant the SA and the SARL (private limited liability company) in some fields of activity.

A new paragraph was added to art. 242-11 by the Law of 12 July 1999, which provides that in derogation from the provisions of the first paragraph of this article requiring the statutory auditor to make a report to the members on the relevant agreements, when the company has only one member it is only necessary to mention such agreements in the register kept by the company of decisions taken by it. It should be noted that the other provisions of art. 262-11, which have been mentioned above, are also applicable to single member companies.

The rules contained in art. 262-11 are stated by art. 262-12 to be inapplicable to agreements governing current transactions and concluded under normal conditions. A similar rule applies to SAs, but not to SARLs.

In addition to the agreements regulated by art. 262-11 and 262-12, certain other agreements are covered by art. 262-13. These agreements are in fact prohibited. The president and the managers cannot enter into any form of loan agreement with the company, be granted an overdraft by it in a current or other account, or have their obligations in relation to third parties guaranteed by the company if they held office at the time of the carrying out of the company's undertaking. Agreements which infringe this prohibition are void.

\section{Concert parties}

Individuals or companies are treated as acting in concert when they have agreed to acquire or transfer shares or use voting rights with the intention of pursuing a common policy towards the issuer (Law of 24 July 1996, art. 256-1-3, paragraph 1). It is often difficult to prove such joint action and so it is presumed in certain cases. Thus, action in concert is presumed between the members of an SAS and the companies which it controls (art. 356-1-3, final paragraph). This presumption is therefore applicable where it is necessary to inform a company that certain thresholds have been crossed in relation to share ownership, and in relation to transactions involving the acquisition of control. As is to some extent the case under English law, the concert parties are treated as though they were a single person (see Companies Act 1985, s. 205). If the members of an SAS hold more than one third of the capital of a quoted 
company, they are required to make a public offer for the remainder (Regulations of the Stock Exchange Commission, art. 5-4-1).

\section{Other restrictions based on general company law}

An SAS is a company limited by shares. As already indicated, it is subject to all the rules governing such companies, except those governing general meetings, management and administration (art. 262-1, para. 2 of Law of 24 July 1966, as amended; see Guyon, op. cit., p. 561 for a clear account of the governing rules). The rules governing the accounts of such a company are thus similar to those applicable to those of an SA. However, the Fourth and Seventh Directives on company accounts do not seem applicable to such companies. Shareholders of the company holding individually or collectively may petition the court to appoint one or several experts to report on one or more management decisions (art. 226 of the Law of 1966), or to dismiss any statutory auditor who cannot properly fulfil his functions (art. 227, ibid.). The rules contained in Law No. 66-537 of 24 July 1966 governing the SAS are applicable to the formation, the nullity, and the dissolution and liquidation of such companies, as well as their merger with other companies and their decision. The rules contained in art. 360 of the 1966 law concerning the amendment of resolutions of an SA are also applicable to an SAS.

All French civil and commercial companies are governed by the general principles contained in art. $1832 \mathrm{ff}$ of the Civil Code. These rules entail that the allocation of profits and losses shall not take place in an arbitrary way which is unfair to individual shareholders; that the rights of such shareholders must correspond to their shares in the company's capital, and that the obligations of shareholders cannot be increased without their individual consent. Furthermore, shareholders have the right to be informed of and to participate in collective decisions.

\section{RESTRICTIONS ON TRANSFER OF SHARES: EXCLUSION OF MEMBERS}

The above mentioned matters are regulated by art. 262-11 to 262-21. It must first of all be noted that provisions may only be included in the statutes of an SAS concerning restrictions on the transfer of shares and the exclusion of members, if all the members agree thereto. The relevant provisions of art. 262-14 to 262-20 concerning these matters are not applicable to single member companies.

Guyon (op. cit., ZGR, 1994, p. 561) contends that the existence of the above provisions may be explained on the basis of the 'personalistic' character of the company, which is thought of as involving the mutual loyalty, trust and co-operation of members who are generally known to one another. These provisions would seem likely to help to maintain such a character. It may well be the case that, like German private companies, the SAS will come to be used for different purposes, and that certain of them may not be of a markedly personalistic ch acter.

\section{Restrictions on share transfers}

According to art. 262-14, the statutes of a company may provide that its shares shall be inalienable for a maximum period of ten years. Such a restriction may be imposed on all shares, or only on the shares of a particular class. It follows from art. 26216 that any purported transfer of such shares is a nullity. Such clauses may be of use in enterprises whose success cannot be guaranteed for some period of time: they may, of course, give rise to conflict. Article $262-15$ provides that the statutes of the company may require the latter's prior approval for any share transfer. This type of clause is sometimes encountered in the statutes of public companies. However, in contrast with the position of such companies, the approval clause in the statutes of an SAS seems applicable to any form of transfer. It may well prove valuable in conserving the identity of the members of the company. However, it may be difficult to determine whether an operation which takes place by reason of a merger or division is to be properly regarded as a share transfer, and thus the company's statutes should perhaps specifically provide whether the approval clause applies to such transactions. They should also specify which body has to give its approval, by what majority, and whether the intending transferor may vote in connection with the decision.

There is nothing in art. 262-15 specifically stating what is to happen if agreement is refused. However, it would seem that the rules which have been applied by the courts where this situation occurs in public companies (Paris, December 21 1983, Revue des Sociétés, 1989 , p. 51) are also applicable to the SAS, which is thus itself required to purchase the shares if approval is refused.

The price at which the shares may be transferred may be determined in accordance with the provisions of the statutes, or by agreement between the parties, or by an expert in accordance with the requirements of art.1843-4 of the Civil Code (art. 26219, Law of 24 July 1966, as amended). In some cases, it may well prove advantageous for the vendor if the price has not been fixed by, or in accordance with the states. It seems, however, that the vendor might have the remedy of refusing to sell his shares if the price fixed was unduly low. (see Guyon, op. cit., ZGR, 1994, p. 563). It is not clear whether the courts have any control over the method of fixing the price stipulated in the statutes (see Guyon, op. cit., Die AG, 1994, p. 453).

\section{PITFALLS}

The largely contractual basis of the new French entity may give rise to pitfalls for inexperienced people who lack adequate legal advice and fail to make adequate provision for certain necessary matters in the statutes of the SAS

\section{The exclusion of members}

There appears to be some doubt as to whether exclusion clauses in the statutes of a company are generally permissible under French law. However, art. 262-17 provides that under conditions stated therein, the statutes may provide that a member is bound to transfer his/her shares. It also stipulates that the pecuniary rights of a member who does not proceed with such a transfer may be suspended. It will be noted that art. 262-17 does not attempt to stipulate the circumstances under which a member may be excluded. art. 262-19, paragraph 2 provides that if the shares are purchased by the company, the latter is bound to transfer them within a period of six months, or to cancel them. 
The statutes of the company should prescribe whether the shares of the member who is excluded should be purchased by the company, or by a member or members thereof. They should also state the grounds for exclusion (which may well include repeated personal conflicts with other members), mention which organ is competent to decide thereon, and give the member affected particulars of the grounds. Furthermore, it may be desirable for them to require that the member should be present when the decision is to be taken, and state the period of time within which the exclusion is to take place. (See Kindler and Seseke, op. cit., Die AG, 1994, p. 454. The authors consider it advisable that the statutes should contain rules governing the evidential burden of the existence of a ground for exclusion).

It appears that a decision to exclude a member is subject to review by the courts if the requirements of the statutes have not been complied with, or perhaps if the consideration to be given for the shares manifestly fails to reflect their real value. However, it appears to follow from art. 360 of the Law of 24 July 1966 that legal transactions entered into by, and resolution of, an SAS must be annulled within three years. Such resolutions may be treated as including decisions by the organ competent to decide on the exclusion of a member.

A more limited provision concerning the exclusion of a member is contained in art. 262-18. This rather complex provision stipulates that the statutes may provide that where the control of a company or partnership which is a member of an SAS is altered within the meaning of art. 355-1 of the law of 24 July 1966 (as amended), the latter company or partnership must inform the SAS. The provisions of art. 355-1 are themselves rather complex. They are fully set out in Le Gall and Morel, French Company Law, 2nd ed., Longmans (1992), pp. 240-1. The SAS may decide in accordance with the requirements laid down by the statutes to suspend the non-pecuniary (e.g. the voting) rights of the relevant member, or to exclude it. Article 262-18 does not say how the exclusion is to take place. This, it seems, will usually (if not invariably) take place by means of compulsory transfer of the shares. The former dispositions are said to apply also to a member which acquires that status as the result of a merger or division or the dissolution of a company.

The provisions of art. 262-18 are rather obviously intended to conserve the personalistic character of the company.

The rules governing the price which has be paid when shares are transferred in pursuance of an approval clause, and the statutes of the company do not contain any provisions governing how the sale price is to be calculated, are also applicable where the company's statutes contain a provision based on art. 217-17 or 217-18, but contain nothing about the calculation of the transfer price. Thus the latter may be agreed on between the relevant parties, or as a result of an arbitration procedure conducted by an expert, in accordance with art. 1843-4 of the Civil Code.

There is nothing in the legislation of 1994 or 1999 governing the voluntary withdrawal of members of an SAS. This is frequently permissible under US close company statutes, and may take place in a German $\mathrm{GmbH}$ (private limited liability company) where the statutes of the company so provide, and if they do not, where there is serious reason for it. It may well be the case that withdrawal from an SAS is permissible under French law where the statutes provide for it.

\section{FINAL REMARKS}

It is difficult to predict the future of the SAS following its 'liberalisation' in 1999. When the new regime comes to be more generally understood, the SAS may well tend to supplant the SA and the SARL (private limited liability company) in some fields of activity. Although the new regime is more comprehensive and useful than that contained in the German law of 9 August 1994 (BGBI1.1961) on small public companies, it still appears rather complex, and also fails to include any special protective provisions for minority shareholders comparable to those contained in s. 459-461 of the Companies Act 1985, which have their counterparts in the Republic of Ireland and most Commonwealth countries. The largely contractual basis of the new French entity may give rise to pitfalls for inexperienced people who lack adequate legal advice and fail to make adequate provision for certain necessary matters in the statutes of the SAS.

Although it is likely that a new type of limited partnership may soon be available in the UK for two or more persons engaged in trade, industry and the professions, there does not seem to have been any demand for the introduction of a new entity corresponding to the SAS. Such a demand may perhaps come about if and when recent developments in France, and prospective ones in Germany, become more widely known. (c)

\section{Frank Wooldridge \\ University of Notre Dame, London}

\section{Further reading}

An article by Frank Wooldridge on 'German legal entities suitable for attorneys' appeared in Amicus Curiae, Issue 26, April 2000, at p. 28.

\title{
Amicus Curiae
}

\section{Submission of articles}

Readers of Amicus Curiae are welcome to submit contributions (not exceeding 3000 words) for publication. Information, including author style notes, is available on the Internet at: http://ials.sas.ac.uk/amicus.htm

\author{
Please contact Julian Harris for further information at: Institute of Advanced Legal Studies \\ 17 Russell Square, London WC1B 5DR \\ E-mail:julian.harris@sas.ac.uk
}

